\title{
PENGOLAHAN MATERIAL BAMBU DENGAN MENGGUNAKAN TEKNIK LAMINASI DAN BENDING UNTUK PRODUK FURNITURE
}

\author{
Oleh: Hari Nugraha, M.Ds
}

\section{ABSTRAK}

Bambu adalah sebuah material alternatif dari kayu yang banyak digunakan untuk pembuatan furniture. Dengan menggunakan rotan sebagai tali pengikat untuk sambungan, bambu dapat dibentuk menjadi furniture dengan nilai estetik. Penelitian ini meneliti cara baru dalam pemprosesan furniture yang terbuat dari bambu. Metode yang digunakan adalah teknik laminasi yang digunakan untuk membuat balok atau papan bambu dan teknik penguap bertekanan untuk proses penekukan. Keluaran dari penelitian ini yaitu dua teknik yang inovatif untuk pemprosesan bambu secara modern. Hasil penelitian ini dapat digunakan oleh khalayak umum dan usaha kecil yang berkecimpung dalam industri kerajinan bambu.

\section{ABSTRACT}

Bamboo as an alternative material besides timber has been widely used for furniture. With the use of rattan as the rope to make joints, bamboo can be shaped as furniture with aesthetic value. This research investigates a new way in processing bamboo furniture. The method uses the laminating technique in processing bamboo to become bamboo block or board and the pressured steam technique in bending them. The use of these two innovative techniques is aimed to find a modern method in processing bamboo. The outcome of this research can be used by general public and small business enterprise in bamboo crafts.

\section{TINJAUAN TEORITIS DAN PERUMUSAN HIPOTESIS}

\subsection{JENIS BAMBU}

Untuk menentukan jenis bamboo yang akan diteliti untuk melakukan eksperimen proses laminasi dan bending bamboo, mengacu kepada data-data yang telah dikumpulkan yaitu dari sumber pustaka :

KOLEKSI JENIS-JENIS BAMBU PUSAT PENELITIAN DAN PENGEMBANGAN HUTAN DAN KONSERVASI ALAM BOGOR DI STASIUN PENELITIAN HUTAN ARCAMANIK, BANDUNG

oleh : Sutiyono

Berikut ini jenis-jenis bamboo berdasarkan sumber pustaka tersebut :

a. Bambusa arundinaceae (Retz.) Willd.

Bambu ini berasal dari Thailand, nama lain yaitu bambu duri, haur cucuk, bambu duri liar, ciri fisik percabangan dimulai dari buku paling bawah, pada ketiak ranting dengan cabang terdapat duri, pelepah batang bermiang lebat, warna gelap, tidak mudah gugur dan tanpa kuping pelepah daun. Rumpun rapat 8 batang $/ \mathrm{m}$. Tinggi batang dapat mencapai $12 \mathrm{~m}$ dengan diameter $11 \mathrm{~cm}$.

Daerah penyebaran, Sumbawa (NTB), Gowa, (Sulawesi Selatan).

Penggunaan bamboo jenis ini yaitu batang untuk bahan bangunan oleh penduduk setempat, anyaman, kertas, sumpit. Rebung dapat digunakan sebagai sayuran.

\section{b. Bambusa vulgaris.}

Nama lokal yaitu haor koning (Sunda), pring ampel (Jawa), Penyebaran alami : Sumatera, Jawa, 
Madura, Bali, Lombok, Sumbawa, Kalimantan, Sulawesi, Maluku, Irian Jaya.

Ciri fisik yaitu batang berwarna hijau, rumpun bamboo berjarang 4 batang $/ \mathrm{m}$, tinggi dapat mencapai $10 \mathrm{~m}$ dengan lingkar diameter luar $9 \mathrm{~cm}$. Bambu jenis ini ada 2 yaitu yang berwarna batang hijau muda dengan bentuk fisik batang bamboo lurus dan jenis ke 2 yaitu batangnya tumbuh membengkok/melengkung.

Pemanfaatan bamboo untik pembuatan anyaman, kertas, partikel board, dan furniture.

\section{c. Bambusa maculata Widjaja}

Nama lokal : Awi totol (Sunda), pring tutul, pring loreng (Jawa) Daerah penyebaran yaitu Sumatera, Jawa, Madura, Bali, Lombok, Sumbawa, Kalimantan, Sulawesi, Maluku, Irian Jaya.

Ciri fisik batang bamboo berwarna hijau tua, dan pada batang bagian pangkal muncul sedikit garisgaris kuning, tumbuh tegak lurus, tinggi batang mencapai 9 meter dan diameter lingkar pangkal $9 \mathrm{~cm}$, bagian percabangan dimulai dari bagian buku tengah, cabang ranting bamboo pendek dan tidak panjang. Pemanfaatan batang bamboo untuk pembuatan anyaman, kertas, partikel board, furniture.

\section{d. Dendrocalamus asper}

Nama daerah : trieng betong (Aceh), oloh otong (Gayo), bulu botung (Batak), lewuo guru (Nias), bambu batueng (Minangkabau), pering betung (Lam-pung) awi bitung (Sunda), pring petung, deling petung, jajang petung (Jawa), pereng petong (Madura), tiing petung (Bali), au petung (Solor), bulo patung (Sangihe).

Ciri fisik bambu yaitu berbatang besar dengan diameter pangkal batang dapat mencapai $26 \mathrm{~cm}$ dan tinggi batang $>25$ meter, dibagian buku ruas ke 1 - 11 terdapat lingkaran akar yang sangat menonjol, memiliki daun lebar, percabangan yang menonjol pada buku ke 8-10. Terdapat 3 jenis warna batang bamboo yaitu jenis petung coklat, petung hijau, petung kuning.

\section{e. Gigantochloa atroviolaceae Widjaja}

Nama daerah : bambu hitam (Sumatera), awi hideung (Sunda), pring wulung (Jawa). Ciri fisik batang bamboo berwarna hitam sampai hitam keungunan. Bambu jenis ini ada juga yang memiliki warna hitam/ungu bercampur dengan warna hijau. Ruas-ruas bamboo sedikit membengkok pada buku. Kerapatan rumpun bamboo tergolong jarang $2 \mathrm{batang} / \mathrm{m}$. Tinggi batang bambu mencapai 12 meter dengan lingkaran diameter $11 \mathrm{~cm}$. Daerah penyebaran di Indonesia yaitu Sumatera, Jawa. Batang bamboo dimanfaatkan untuk bahan bangunan, anyaman, lokal furniture, alat angklung (kesenian Sunda), papan serat semen,

\section{f. Gigantochloa atter (Hask.) Kurz.}

Nama daerah : bambu ater, awi ater, awi temen (Sunda), pring legi, pring jawa, pring benel (Jawa), tiying jawa, bambu jawa (Bali), air santong (Lombok, Sumbawa). Ciri fisik yaitu batang berwarna hijau muda ke hijau tua, ruas-ruas sedikit membengkok pada buku. P ercabangan dimulai dari buku bagian tengah sampai ujung. Kerapatan rumpun agak rapat, 5 batang $/ \mathrm{m}$. Tinggi batang mencapai hingga 12 meter dengan lingkaran diameter luar $11 \mathrm{~cm}$. Pemanfaatan bamboo untuk bahan bangunan, papan serat semen, anyaman, kertas, sumpit; Rebung: rasa manis sehingga dapat digunakan sebagai sayuran.

\section{g. Sifat dan Karakteristik Bambu.}

Menurut Dransfield dan Widjaja (1995) kolom yang terdapat pada batang bamboo terdiri dari 50\% parenkim, $40 \%$ serat dan $10 \%$ sel penghubung (pembuluh dan sieve tube). Untuk pengolahan sebuah produk dengan menggunakan material bamboo, harus diketahui terlebih dahulu sifat fisis dan sifat mekanis dari material bamboo yang akan digunakan. Ginoga (1977) menjelaskan bahwa beberapa aspek tertentu dapat mempengaruhi sifat fisis dan mekanis dari material bamboo yaitu seperti umur bamboo, posisi ketinggian tumbuh batang bamboo, diameter bamboo, ketebalan daging bamboo, posisi beban (pada buku atau ruas), posisi radial batang bamboo dan kadar air yang terdapat pada bagian batang bamboo.

Daya tahan bamboo terhadap kondisi alam masih menjadi kendala untuk pemanfaatan aplikasi material bamboo untuk produk fungsional. Serangan rayap yang menyebabkan daging bamboo menjadi bubuk merupakan salah satu kelemahan yang dimiliki oleh material bamboo, untuk aplikasi produk seperti untuk produk furniture pemilihan material bamboo harus diambil dari jenis bamboo yang relatif tahan terhadap serangan rayap bubuk, dari hasil penelitian Jasni dan Sumarni (1999) bamboo atter (Gigantochloa Atter) dan bamboo Apus/Tali (Gigantochloa Apus) relatif tahan terhadap serangan rayap bubuk, sehingga sesuai untuk digunakan sebagai bahan dasar untuk produk pakai fungsional seperti untuk produk furniture.

\subsection{TEKNOLOGI PRODUKSI BAMBU LAMINASI \\ 1.2.1. TEKNOLOGI PRODUKSI BAMBU LAMINASI OLEH LITBANG UPT BPP BIOMATERIAL LIPI}

Litbang UPT BPP biomaterial LIPI mengembangkan pengolahan material bamboo yang diberi nama Bambu Komposit. Pengembangan material tersebut dimaksudkan untuk menjadi material alternatif pengganti kayu. 
Proses pembuatan bamboo komposit atau secara umum dikenal dengan laminasi bamboo, diproses dengan cara membentuk batang bamboo menjadi potongan pipih kemudian disatukan dan dibentuk menjadi balok atau papan kemudian diberikan bahan perekat dan dipres. Dari hasil penelitian Litbang UPT BPP biomaterial LIPI Kekuatan bambu komposit untuk uji bending strength sangat baik dan dapat melebihi kayu jati.

Dengan perekat phenol formaldebida atau isocyanate, papan atau balok bambu komposit dapat digunakan sebagai bahan bangunan di luar ruangan (outdoor) seperti rumah kebun, pagar halaman, dinding penyekat jalan tol, jembatan, dan lain-lain. Sedangkan dengan perekat urea formaldebida, papan atau balok bambu komposit dapat digunakan untuk bahan bangunan di dalam ruangan (indoor), seperti dinding rumah, pintu, mebel, dan lain-lain. Papan bambu komposit ini dapat dikembangkan untuk berbagai produk dengan spesifikasi teknis (dimensi, kerapatan), bentuk, tujuan pemakaian (indoor atau outdoor) dan kegunaan sesuai dengan permintaan.

Berikut ini tabel data hasil pengujian bamboo komposit yang dilakukan oleh Litbang UPT BPP biomaterial LIPI :

\begin{tabular}{|l|l|c|}
\hline No & Sifat yang diuji & Papan bambu PF \\
\hline 1. & Kadar air (\%) & 12.33 \\
\hline 2. & Kerapatan $\left(\mathrm{g} / \mathrm{cm}^{3}\right)$ & 0.72 \\
\hline 3. & Pengembangan tebal $(\%)$ & 6.75 \\
\hline 4. & Penyerapan air $(\%)$ & 37.12 \\
\hline 5. & Internal bond $\left(\mathrm{kg} / \mathrm{cm}^{2}\right)$ & 4.96 \\
\hline 6. & Screw withdrawal $\left(\mathrm{kg} / \mathrm{cm}^{2}\right)$ & 40.93 \\
\hline
\end{tabular}

( Tabel 1 hasil pengujian bamboo komposit oleh Litbang UPT BPP biomaterial LIPI )

\subsubsection{TEKNOLOGI PRODUKSI BAMBU LAMI- NASI OLEH SULASTININGSIH}

Hasil penelitian yang dilakukan oleh I.M. Sulastiningsih dengan judul :

BEBERAPA SIFAT BAMBU LAMINA YANG TERBUAT DARI TIGA JENIS BAMBU

(Some Properties of Laminated Bamboo Board made from Three Bamboo Species)

Berikut ini kutipan dari Abstrak hasil penelitian tersebut :

"Penelitian ini bertujuan untuk mempelajari kemungkinan penggunaan bambu lamina sebagai bahan substitusi kayu, khususnya mengetabui pengarub jenis bambu terhadap sifat bambu lamina yang direkat dengan urea formaldebida. Bambu yang digunakan dalam penelitian ini adalah bambu andong (Gigantochloa pseudoarundinacea), bambu mayan (Gigantochloa robusta) dan bambu tali (Gigantochloa apus) yang berasal dari tanaman rakyat di Jawa Barat. Hasil penelitian menunjukekan babwa beberapa sifat bambu lamina dipengarubi oleh jenis bambu yang digunakan kecuali kadar air, keteguhan tekan sejajar serat dan keteguban rekat. Kerapatan bambu lamina bervariasi antara 0,62 - 0,79 $\mathrm{g} / \mathrm{cm} 3$. Bambu lamina dari bambu tali memiliki nilai keteguhan lentur tertinggi sedangkan bambu lamina dari bambu mayan memiliki keteguban lentur terendah. Keteguban rekat bambu lamina yang diuji dengan cara geser tekan bervariasi antara 67,03 - 86,19 kg/ cm2 dan 54,43 - 62,94 kg/ cm2 berturutturut untuke uii kering dan uji basah. Sifat perekatan bambu lamina dari bambu andong, mayan dan tali cukup baik. Bambu lamina (3 lapis) masing-masing dari bambu andong, mayan dan tali setara dengan kayu kelas kuat II. Pembuatan bambu lamina secara teknis dapat dilakukan dan produk tersebut dapat digunakan sebagai bahan substitusi kayu."

\subsubsection{TEKNOLOGI PRODUKSI BAMBU LAMINASI OLEH PROF. DR. IR. MoriSco (UGM)}

Morisco pada tahun 2004 mengembangkan teknik laminasi bambu dalam bentuk papan dan balok sebagai material untuk pembuatan dinding, lantai, daun pintu, mebel dan kusen.
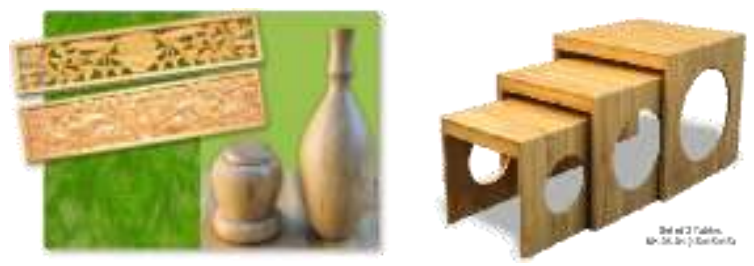

Gambar 1.3.3-2

Hasil Produk dari Material Balok Bambu Sumber : www.moriscobamboo.com

\subsection{TEKNOLOGI PRODUKSI BAMBU TEKUK (bending)}

\subsubsection{TEKUK BAMBU DENGAN TEKNIK PEMANASAN}

Teknik yang dapat diaplikasikan untuk membengkokkan batang bamboo adalah dengan cara memanaskan pada area dibagian yang akan dibengkokkan, pemanasan permukaan batang bamboo dapat dilakukan dengan api gas atau api las, atau dapat dilakukan diatas kompor dan harus dilakukan secara hati-hati. Batang bamboo yang akan di bengkokkan /bending, dipanaskan di atas api selama beberapa detik kemudian memutar batang bamboo tersebut dan segera lakukan proses bending atau menekuk batang bamboo tersebut ke dalam bentuk yang diinginkan. Ketika bambu mendingin, bentuk permukaan batang bamboo yang telah ditekuk akan permanen pada posisinya. 
Teknik Pembakaran (Roasting) oleh : Zhu Zhaohua, Distinguished Fellow of INBAR for Life and Jin Wei, Publications and Training

INTERNATIONAL NETWORK FOR BAMBOO AND RATTAN (INBAR)

Roasting adalah metode yang umum digurakan di Cina untuk mengolah batang bambu, batang bambu yang diletakkan di atas api atau uap panas bertujuan sebagai berikut:

- Melunakkan batang (serat) bamboo.

- Mempercantik penampilan luar batang bamboo dengan efek bakar.

- Mengurangi atau menghindari penyusutan produk jadi.

Metode ini dapat digunakan untuk meluruskan batang melengkung atau membentuk kurva dengan batang lurus.

Cara memanaskan batang bamboo yaitu dengan: pasir diisi dalam batang bamboo sebelum pemanasan, pasir di dalam batang mabu dapat mencegah dinding bambu untuk melebar dan pecah akibat panas yang tidak merata.

\subsubsection{BENDING KAYU DENGAN TEKNIK UAP}

Penelitian yang dilakukan oleh David Smith (2004) untuk melakukan proses bending pada material kayu menggunakan steam box, teknik ini memungkinkan bentuk dan ukuran material kayu yang bervariasi. Untuk ukuran material yang kecil, dapat menggunakan pipa PVC sebagai pengganti steam box. Jenis kayu yang paling baik untuk dilakukan proses bending dengan cara steam (penguapan) yaitu White Oak.

Hasil penelitian lain yang dilakukan oleh Achmad Supriadi and Osly Rachman untuk proses bending material kayu yaitu :

Hasil pelengkungan 5 jenis kayu yang telah diberi praperlakuan perendaman dengan larutan $\mathrm{NaOH}$ $3 \%$ menunjukkan bahwa kayu asam jawa termasuk baik, kayu marasi sedang, kayu balobo jelek, kayu kendal dan rasamala sangat jelek.

Praperlakuan sebelum kayu dilengkungkan dan jenis kayu berpengaruh nyata terhadap radius pelengkungan. Kayu yang diberi perlakuan awal perendaman dengan larutan $\mathrm{NaOH} 3 \%$ lebih mudah dilengkungkan dibandingkan dengan yang tidak direndam. Tidak ada perbedaan nyata radius pelengkungan antara kelima jenis kayu, kecuali antara kayu rasamala dengan keempat jenis kayu lainnya.

Analisis regresi antara sifat fisis kayu dengan radius pelengkungan menunjukkan tidak ada hubungan nyata antara kerapatan kayu dengan radius lengkung, sedangkan antara radius Radius lengkung (Bending radius), lengkung dengan pengembangan
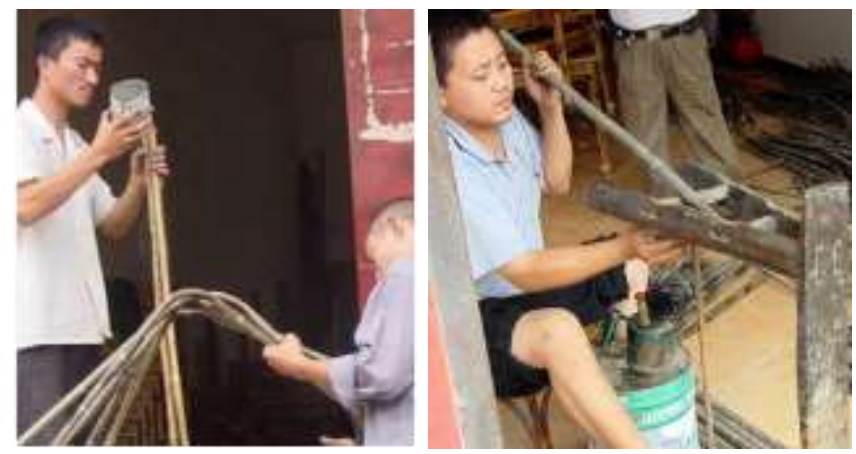

Gambar 1.4.1-1

Memasukkan Pasir Ke Batang Bambu \& Proses Tekuk, Sumber : INBAR

dimensi kayu menunjukkan hubungan yang sangat nyata dengan persamaan $\mathrm{Y}=57,1963-2,6213 \mathrm{X}$ dengan $\mathrm{R} 2=0,26$

\section{ARAH PENELITIAN PROSES LAMINASI DAN BENDING BAMBU}

Dari hasil data yang didapat dan berdasarkan penelitian sebelumnya yang pernah oleh Prof. Morisco dalam pengolahan material bamboo, kemudian dirumuskan untuk mencari sebuah alternatif teknik untuk pengolahan material bamboo, teknik pengolahan bamboo tersebut kemudian akan diuji dengan menggunakan metode eksperimental.

Eksperimen yang akan dilakukan yaitu penerapan teknik laminasi bamboo dan proses bending (tekuk) material bamboo dengan menggunakan sistem steam/uap bertekanan, dari hasil eksperiment tersebut kemudian akan dilanjutkan ke proses desain untuk diaplikasikan menjadi sebuah produk pakai fungsional untuk produk furniture.

Berikut ini rincian tahapan penelitian yang akan dilakukan yaitu sebagai berikut :

a. Eksperimen dan Pra Desain :

- Pemilihan jenis bamboo yang akan digunakan untuk eksperimen.

- Proses laminasi bamboo untuk dibentuk menjadi balok atau papan.

- Proses pembuatan moulding untuk bending bamboo.

- Pembuatan tabung uap bertekanan.

- Proses eksperimen bending dengan teknik uap bertekanan.

- Analisis hasil eksperimen bending material (kekuatan material \& kerapatan hasil lami nasi bamboo setelah dilakukan proses bending)

b. Proses Desain

- Pembuatan gambar desain furniture bamboo (tempat duduk). 
- Membuatan gambar kerja.

- Pembuatan komponen furniture.

- Perakitan komponen.

Arah penelitian dalam proses pembuatan laminasi dan bending bamboo ini yaitu menggunakan pendekatan kerja manual dengan memanfaatkan dan merekayasa peralatan kerja sederhana untuk melakukan peroses laminasi dan bending bamboo. Diharapkan, dengan peralatan kerja manual dan sederhana yang mudah untuk didapat tersebut tidak akan membebani dari aspek biaya investasi awal pengadaan alat bantu kerja untuk industri kecil furniture bamboo.

Peralatan manual yang digunakan untuk proses laminasi bamboo yaitu terdiri dari :

- Alat potong (gergaji).

- Pisau raut atau golok.

- Klem untuk pres bilah bamboo.

- Balok kayu sebagai dudukan klem untuk pres bilah bamboo.

- Hampelas meter untuk menghaluskan permukaan bilah bamboo

Dengan merujuk hasil penelitian yang telah dilakukan sebelumnya, untuk sistem laminasi bamboo memakai teknik seperti yang dilakukan oleh Prof. Morisco dari UGM yaitu dengan cara membentuk balok bamboo dari susunan lembaran bilah bamboo yang sudah diratakan kemudian dilakukan proses laminasi dengan cara di pres.

Untuk proses bending, teknik yang dilakukan yaitu mengadaptasi dari prinsip dasar bending balok kayu dengan memanfaatkan uap air (steam) seperti yang dilakukan oleh David Smith (2004). Tempat penguapan atau steam box yang digunakan yaitu berbentuk tabung silinder dengan diameter $15 \mathrm{~cm}$ yang dibuat dari material stainlesstell. Penelitian yang dilakukan Sumber uap untuk melakukan proses seteam dihasilkan dari katel masak bertekanan presto.

Berikut ini uraian arah penelitian yang dilakukan berdasar kan penelitian yang pernah dilakukan sebelumnya :

\section{PROSES EKSPERIMEN LAMINASI DAN BENDING BAMBU}

\subsection{PROSES EKSPERIMEN LAMINASI BAMBU}

Untuk merealisasikan arah penelitian proses laminasi dan bending bamboo, dilakukan beberapa eksperimen awal, eksperimen tersebut yaitu terdiri dari :

a. Eksperimen untuk menguji jenis lem yang akan digunakan untuk melakukan proses laminasi bamboo, lem yang diuji yaitu :

- Resin Lycal

- Polyurethane

- PVAC (Poly Vinly Acetate)

b. Eksperimen proses tekuk atau bending bamboo dengan memanfaatkan uap air dengan tujuan untuk meningkatkan sifat lentur dari bamboo. Uap air yang digunakan tersebut bertujuan untuk meningkatkan kadar air yang ada di dalam batang bamboo sehingga meningkatkan sifat lentur dari bamboo. Eksperimen ini diharapkan dapat mengetahui tingkat kelenturan dan ukuran minimal dari jari-jari tekukan (bending) yang dapat dilakukan oleh bilah bamboo yang telah di beru uap air.

Sebelum masuk ketahapan eksperimen, batang bamboo di bentuk menjadi pilah-bilah bamboo dan dikelompokkan menjadi beberapa jenis ketebalan, ketebalan yang akan digunakan yaitu $2 \mathrm{~mm}-5 \mathrm{~mm}$. Jenis bamboo yang digunakan yaitu bamboo hitam dan bambu andong, dua jenis bamboo tersebut akan di uji untuk mengetahui tingkat kelenturannya.

Standar dimensi bamboo yang digunakan untuk eksperimen proses laminasi dan bending yaitu berdasarkan Diameter rata-rata bamboo yang didapat dari penjual bamboo di sekitar wilayah tangerang selatan yaitu $15 \mathrm{~cm}$ dengan ketebalan daging bamboo $1,5 \mathrm{~cm}$.

\begin{tabular}{|l|l|l|}
\hline Proses Pengerjaan & Penelitian sebelumnya & Penelitian yang dilakukan \\
\hline Laminasi bambu & $\begin{array}{l}\text { Sistem laminasi balok bamboo } \\
\text { oleh Prof Morisco }\end{array}$ & $\begin{array}{l}\text { Sistem laminasi balok bamboo dengan mengadaptasi } \\
\text { sistem yang dilakukan oleh Prof Morisco yaitu dengan } \\
\text { cara di lem dan di press. Proses pengerjaan laminasi } \\
\text { mengunakan pendekatan kerja manual dan dengan alat } \\
\text { yang sederhana }\end{array}$ \\
\begin{tabular}{|l|l|} 
Proses laminasi Coil oleh Darasati., MA \\
Dending
\end{tabular} & $\begin{array}{l}\text { Sistem steam box untuk bending } \\
\text { kayu oleh David Smith }\end{array}$ & $\begin{array}{l}\text { Steam box untuk bending kayu di modifikasi menjadi } \\
\text { bentuk tabung silinder dan diaplikasikan untuk material } \\
\text { bamboo, sumber steam diambil dari katel masak bertekan- } \\
\text { an presto. }\end{array}$ \\
\hline
\end{tabular}

(Tabel 2) 
Dari hasil pengolahan pilah-pilah bamboo tersebut, kemudian akan diuji untuk mengetahui kekuatan lem dan untuk menentukan jenis lem yang akan digunakan.

Proses laminasi bamboo yaitu membuat balok dari lapisan pilah-pilah bamboo yang disatukan dengan menggunakan lem kemudian di pres dengan menggunakan klem, ketebalan balok bamboo yang akan dibuat yaitu $2,5 \mathrm{~cm} \mathrm{X} 4 \mathrm{~cm}$ dengan panjang bamboo $40 \mathrm{~cm}$.

Hasil eksperimen laminasi bamboo dengan menggunakan lem Polyurethane dan Resin Lycal terdapat beberapa permasalahan utama yaitu :

Lem sebagai perekat lapisan bamboo menggunakan jenis resin lycal, untuk aplikasi menggunakan material kayu dapat merekat dengan cukup kuat dan dapat masuk kedalam pori-pori kayu (jenis kayu mahoni), sedangkan untuk diaplikasikan pada permukaan lembaran bilah bamboo tidak dapat merekat dengan cukup kuat, setelah melakukan uji tarik pada tiap lembaran bilah bamboo yang di laminasi, lapisan lem dapat terlepas dan menarik serat bamboo.

Penggunaan lem jenis lain seperti lem polyurethane dapat menghasilkan daya rekat yang kuat, tetapi hasil laminasi bamboo menjadi kaku, keras dan tidak dapat di tekuk (bending).

Kesimpulan dari hasil eksperimen yang telah dilakukan untuk jenis lem PVAC (Poly Vinly Acetate) yaitu, lem PVAC dapat meresap kedalam pori-pori permukaan bamboo dan hasil laminasi bamboo yang dihasilkan masih memiliki sifat lentur.

Jenis bamboo yang digunakan tidak berpengaruh terhadap kekuatan rekat lem yang digunakan untuk proses laminasi bamboo.

Daya Tahan terhadap panas dan air untuk Jenis lem yang digunakan seperti Resin lycal, lem polyurethane dan lem PVAC (Poly Vinly Acetate) tidak tahan terhadap suhu panas dan uap air.

\subsection{EKSPERIMEN PROSES TEKUK (bending) baMboo}

Proses eksperimen selanjutnya yaitu melakukan proses bending (tekuk) Proses bending dilakukan dengan memanfaatkan uap air yang dihasilkan dari katel presto.

Bilah bamboo yang akan di bending terlebih dahulu dimasukkan kedalam tabung silinder sebagai tempat untuk melakukan Proses penguapan, bilah bamboo yang akan dibending terlebih harus dilakukan penguapan untuk memaksimalkan sifat lentur dari bamboo kemudian dilanjutkan dengan proses tekuk yang dilakukan bersamaan dengan proses laminasi. Waktu penguapan yang dilakukan untuk bilah bamboo yang akan di tekuk yaitu 60 menit.

Untuk membentuk dan menekuk bilah bamboo yang telah melalui proses penguapan bersamaan dengan proses laminasi, terlebih dahulu harus dibuat mal sebagai dudukan untuk proses pres.

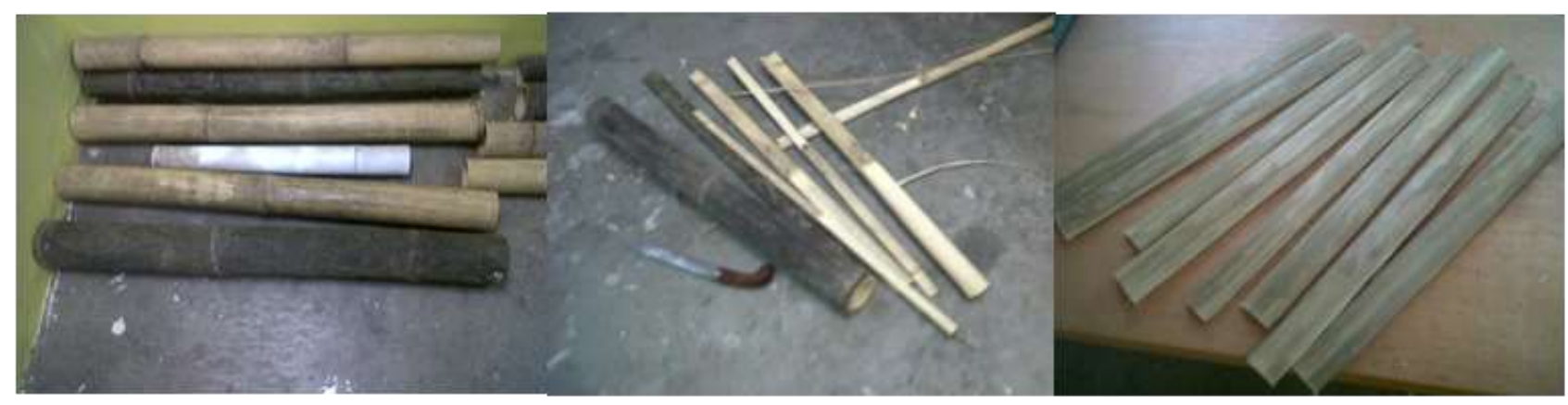

Gambar 3.1-1 : Batang bamboo hitam dan andong sebelum diolah dan proses pembentukan batang bamboo menjadi pilah-pilah bamboo

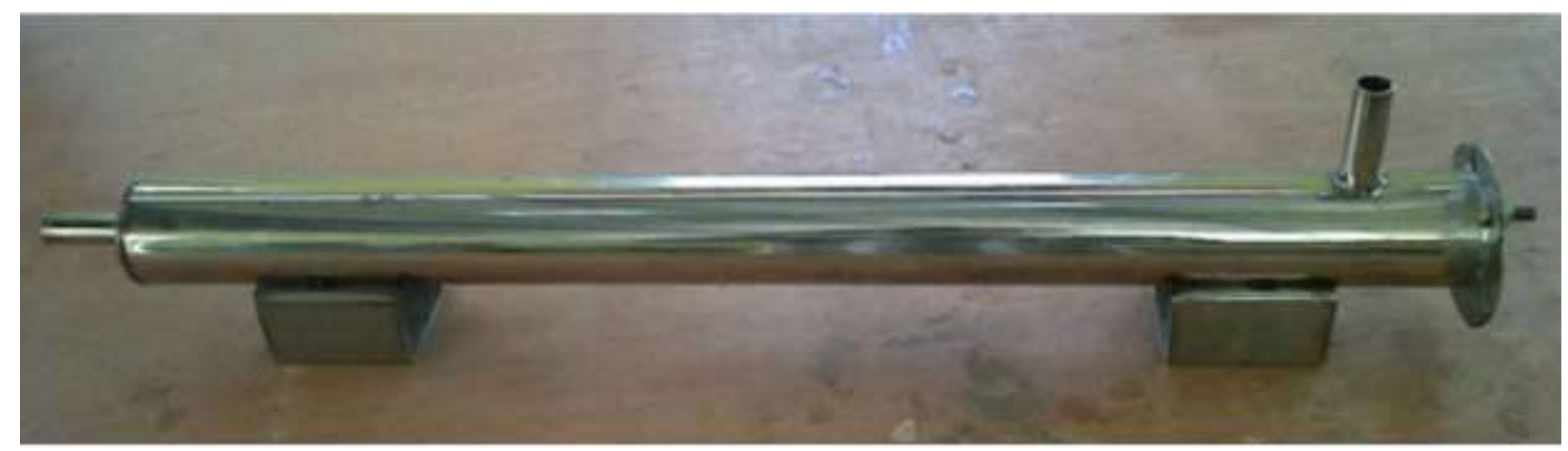

Gambar 3.2-1 : Tabung silinder untuk melakukan proses steam bilah bamboo sebelum di bending. 

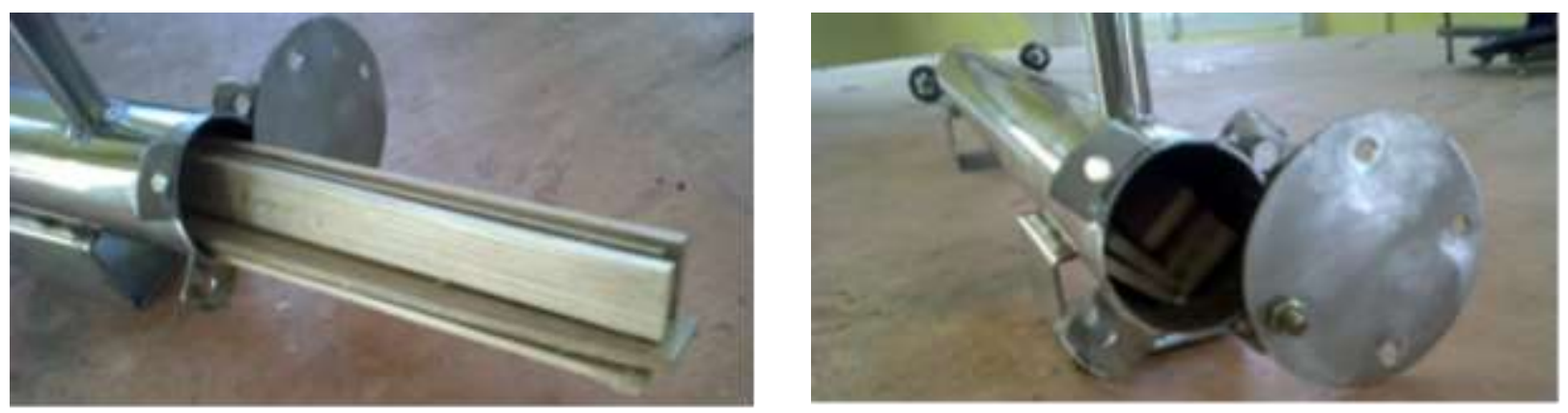

Gambar 3.2-2 : Peroses memasukkan bilah bamboo ke dalam tabung silinder sebelum proses penguapan dilakukan.

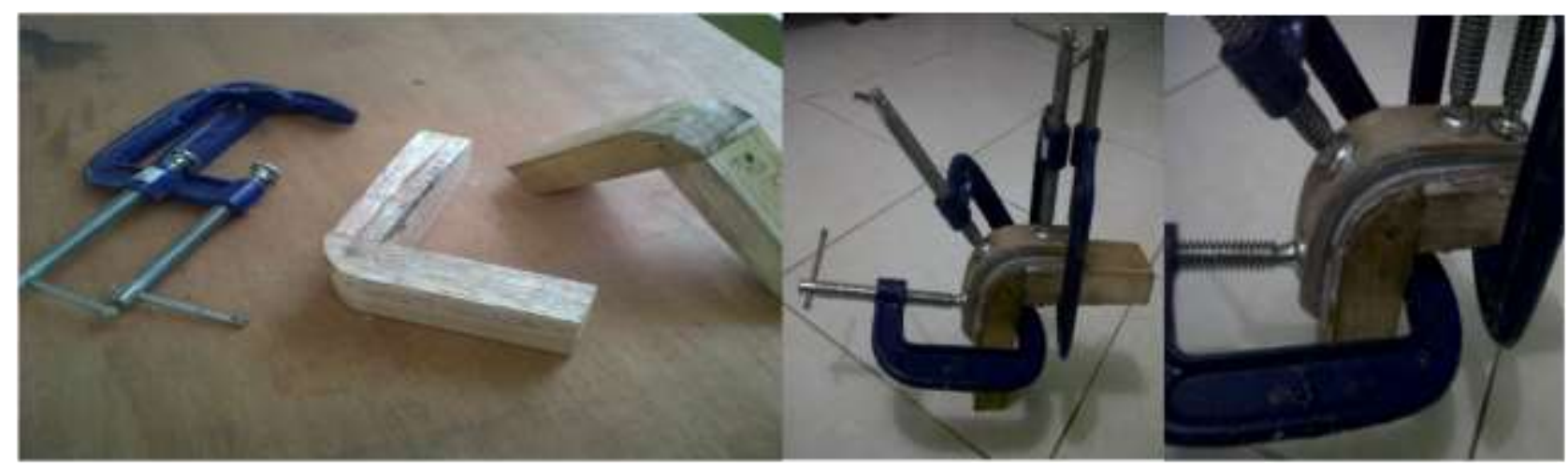

Gambar 3.2-3 : Klem dan mal untuk base tekukan dan pres bilah bambu.

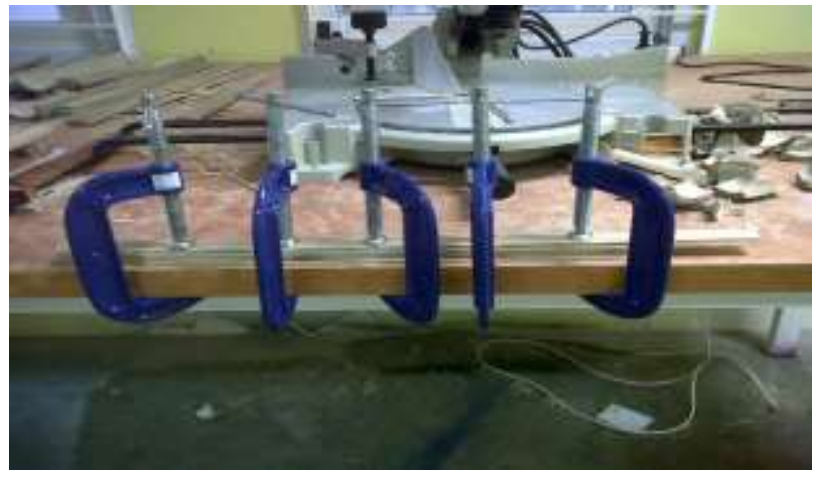

Gambar 3.2-4 : Proses laminasi dan pres bamboo dengan menggunakan jenis lem Polyurethane

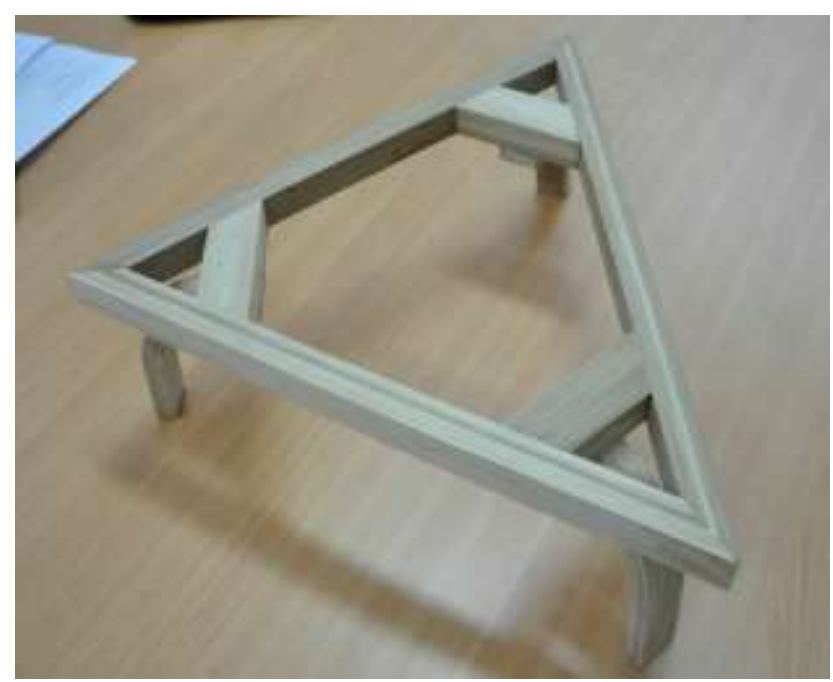

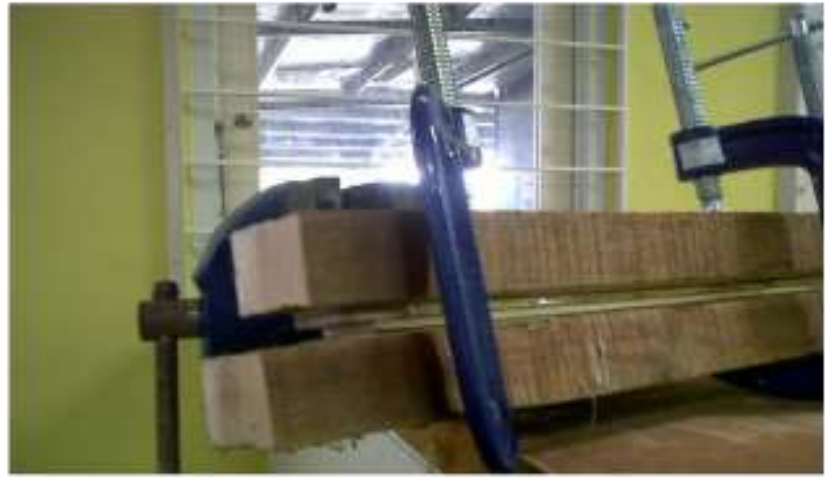

Gambar 3.2-5 : Proses laminasi dan pres bamboo dengan menggunakan jenis lem Resin Lycal

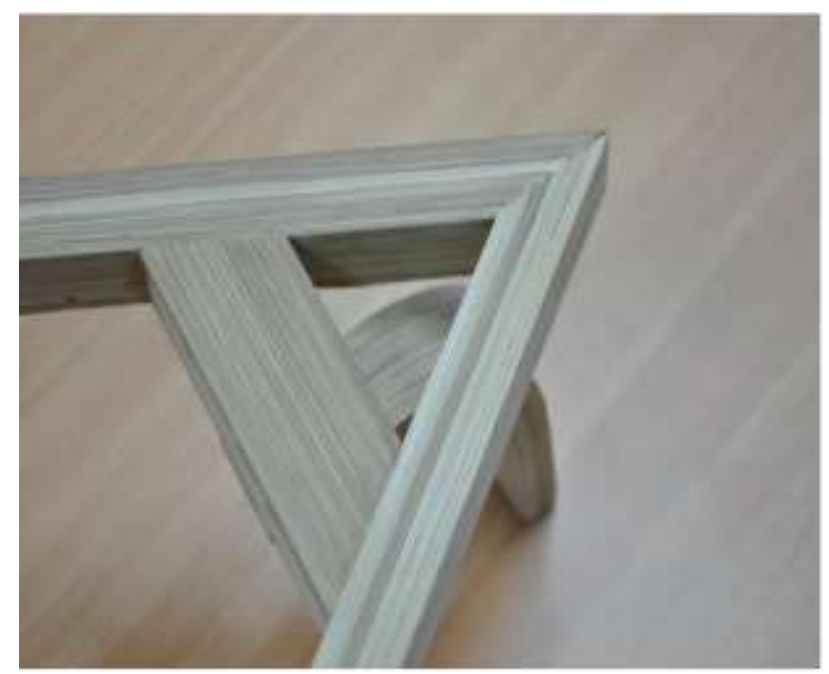

Gambar 3.2-6 : Aplikasi hasil bending bamboo untuk produk furniture (Meja). 

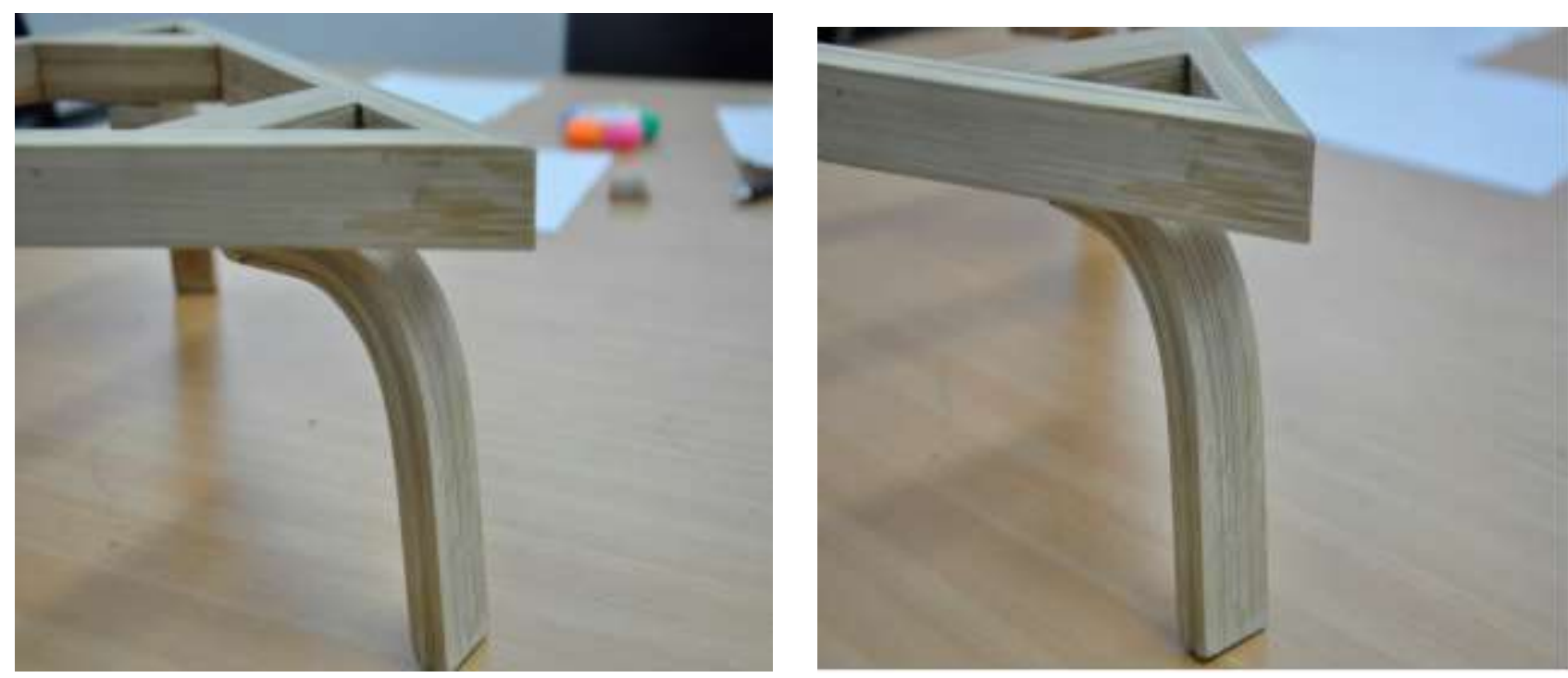

Gambar 3.2-7 : Aplikasi hasil bending bamboo untuk komponen kaki meja bambu.

\subsection{APLIKASI HASIL BENDING DAN LAMINASI BAMBU UNTUK DESAIN FURNITURE}

Aplikasi hasil bending dan laminasi bamboo untuk desain produk furniture yaitu dapat digunakan untuk desain sebuah rangka kursi, hasil laminasi bamboo berbentuk balok dapat digunakan untuk membentuk struktur rangka dan hasil bending laminasi bamboo untuk bagian sudut rangka yang berbentuk lengkungan.

\section{KESIMPULAN}

Penelitian yang telah dilakukan ini masih dalam tahap awal dan perlu untuk di lakukan penelitian lanjutan, terutama untuk menemukan jenis lem/ perekat yang sesuai untuk proses laminasi dan yang tahan terhadap panas dan uap air.

Agar dapat diaplikasikan secara langsung oleh UKM furniture bamboo, proses kerja dan teknik pengerjaan laminasi dan bending yang dilakukan diarahkan untuk dilakukan secara manual dan dengan alat bantu yang mudah untuk didapat atau dibuat.

Proses bending dan laminasi dilakukan pada saat bersamaan dengan cara dipres pada mal yang telah di buat sebelumnya. Proses dengan menggunakan uap air dilakukan untuk memaksimumkan sifat kelenturan bilah bamboo sehingga lapisan bilah bamboo dapat di tekuk ( bending) dengan jari-jari lingkaran yang pendek $(3-4 \mathrm{~cm})$ dengan ketebalan bilah bamboo yang di laminasi dan ditekuk $2-3 \mathrm{~mm}$ dan dengan tebal hasil laminasi $2 \mathrm{~cm}$ dengan jenis lem yang digunakan yaitu PVAC.

Dari hasil penelitian ini, aplikasi yang dapat dilakukan dari hasil bending dan laminasi bamboo untuk desain produk furniture yaitu seperti untuk pembuatan struktur rangka dan untuk bagian sudut atau bentuk struktur rangka lainnya yang berbentuk lengkungan dan memiliki radius lengkungan tertentu.

Waktu penelitian diharapkan dapat diperpanjang untuk memaksimalkan hasil aplikasi bending dan laminasi bamboo untuk membuat sebuah prototype produk furniture kursi yang menggunakan struktur dari material bamboo hasil bending dan laminasi.

Harus dilakukan proses pengujian yang akurat untuk mengetahui kekuatan tekan beban, kekuatan lentur, kekuatan daya rekat lem dan kekuatan fisik permukaan bamboo hasil laminasi dan bending terhadap dampak perubahan kelembapan lingkungan ( diluar ruang dan didalam ruang) serta daya tahan bilah bamboo terhadap serangan jamur.

\section{DAFTAR PUSTAKA}

1. Sulastiningsih I.M. 2005. Beberapa sifat bambu lamina yang terbuat dari tiga jenis bamboo.

2. Sumiati. 206. Pengaruh Jenis Sambungan Balok Laminasi Bambu Wulung Terhadap Keruntuhan Lentur. Jurnal P\&PT Vol IV No 1 (2006) 153-163.

3. M. Mahdavi1; P. L. Clouston, A.M. and S. R. Arwade, A.M. 2011. Development of Laminated Bamboo Lumber: Review of Processing, Performance, and Economical Considerations. American Society of Civil Engineers.

4. Zhu Zhaohua and Jin Wei. 2001. Traditional chinese bamboo furniture processing techniques.

5. International network for bamboo and rattan (INBAR).

6. Sutiyono. 2007. Koleksi jenis-jenis bambu 
pusat penelitian dan pengembangan hutan dan konservasi alam bogor di stasiun penelitian hutan arcamanik, bandung. Prosiding Ekspose Hasil-Hasil Penelitian, 2007

7. Achmad Supriadi and Osly Rachman. 2002. Sifat pelengkungan lima jenis kayu dengan dua macam perlakuan awal (Bending Characteristics of Five Wood Species With Two Types of Pretreatment).

8. Iwan Suprijanto, Rusli, dan Dedi Kusmawan. 2009. Standardisasi bambu laminasi sebagai alternative Pengganti kayu konstruksi. Prosiding PPI Standardisasi 2009.

9. Litbang UPT BPP biomaterial LIPI. 2000. Teknologi Bambu Komposit.

\section{BIOGRAFI PENULIS :}

Hari Nugraha, M.Ds.

Program Studi Desain Produk Universitas Pembangunan Jaya Jl. Boulevard Bintaro Sektor VII Bintaro Jaya, Tangerang Selatan 15224. 